Acta Universitatis Wratislaviensis • No 3869

Literatura i Kultura Popularna XXIV, Wrocław 2018

DOI: $10.19195 / 0867-7441.24 .16$

\author{
Marta Kaprzyk \\ ORCID: 0000-0002-9299-1846 \\ Uniwersytet Wrocławski
}

\title{
Ta śmieszna codzienność. Konwencje i źródła humoru w wybranych współczesnych komediach hiszpańskich
}

\begin{abstract}
Słowa kluczowe: kino hiszpańskie, kino współczesne, komedie, ekonomia kina
\end{abstract}
Keywords: Spanish cinema, contemporary cinema, film comedies, film economy

Wśród dziesięciu najchętniej oglądanych (w Hiszpanii) filmów hiszpańskich $\mathrm{w}$ historii połowa $\mathrm{z}$ nich to komedie ${ }^{1}$. Są one od wielu lat nie tylko jednym z popularniejszych gatunków w tej kinematografii - wśród nich można zaobserwować

${ }^{1}$ Najaktualniejsze dane dotyczące najbardziej kasowych oraz najchętniej oglądanych filmów hiszpańskich prezentuje Wikipedia: https://es.wikipedia.org/wiki/Anexo:Las_diez_pel\%C3\%ADculas_ españolas_más_taquilleras_de_la_historia (dostęp: 5.01.2017). W pierwszej dziesiątce najczęściej oglądanych w Hiszpanii filmów pochodzących z tego kraju (bądź w nim koprodukowanych) znajdziemy: 1. Hiszpański temperament (Ocho apellidos vascos, reż. Emilio Martínez Lázaro, 2014), 2. Inni (Los Otros/The Others, reż. Alejandro Amenábar, 2001), 3. Niemożliwe (Lo imposible/ The Impossible, reż. Juan Antonio Bayona, 2012), 4. Jak zostać Katalonka (Ocho apellidos catalanes, reż. Emilio Martínez Lázaro, 2015), 5. Za kilka dolarów więcej (Per qualche dollaro in più, reż. Sergio Leone, 1965), 6. Torrente 2: Misja w Marbelli (Torrente 2: Misión en Marbella, reż. Santiago Segura, 2001), 7. Liga najgłupszych dżentelmenów (La gran aventura de Mortadelo y Filemón, reż. Javier Fesser, 2003), 8. Siedem minut po pótnocy (A Monster Calls, reż. Juan Antonio Bayona, 2016), 9. Sierociniec (El Orfanato, reż. Juan Antonio Bayona, 2007) oraz 10. No desearás al vecino del quinto (reż. Tito Fernández, 1970). Komedie zajmują w tym zestawieniu pierwsze, czwarte, szóste, siódme i dziesiąte miejsce. Warto zauważyć, że miejsce oglądania tych filmów nie ma znaczenia - film Hiszpański temperament był oglądany w Hiszpanii chętniej niż Inni, jednak w skali światowej to ten drugi tytuł zgromadził w kinach większą widownię, prawdopodobnie z powodu swojej transnarodowej obsady i łatwiej eksportowalnego gatunku (kino grozy). 
również silną tendencję do seryjności oraz powtarzalności motywów ${ }^{2}$. Celem niniejszego artykułu jest próba usystematyzowania najpopularniejszych konwencji wewnątrz gatunku oraz opis źródeł humoru w wybranych współczesnych hiszpańskich komediach filmowych. Zostaną one również omówione w kontekście ekonomicznym.

\section{O naturze komedii}

Steven Marsh podkreśla, że w kulturze hiszpańskiej komedia uznawana jest za wyraźnie narodową formę (ma to swoje źródła przede wszystkim w historii literatury, za przykład badacz podaje literaturę pikarejską). Autor przyznaje, że mimo iż o kulturze popularnej trudno mówić w ograniczeniu do narodowych granic, pewnym jej przejawom nie można odmówić wagi lokalnej specyfiki i topiczności: „Zasadniczo, pomimo roszczeń do uniwersalności, komedia jest często i w sposób najbardziej efektywny — pełna lokalnej specyfiki w zakresie swoich odniesień. W tym kontekście Hiszpania jest rzeczywiście [...] emblematyczna"3. Kino gatunkowe bazujące na dobrze rozpoznawanych kodach i wykorzystujące utrwalone formuły w wypadku komedii hiszpańskiej jest bowiem bardzo silnie związane z pojęciem samej hiszpańskości, która bywa głównym źródłem komizmu. Jak piszą Barry Jordan i Rikki Morgan-Tamosunas, podczas gdy hiszpańskie kino gatunków odpowiada transnarodowym kulturowym trendom, w tym samym momencie wykazuje przejawy własnej kulturowej specyfiki w różnorodnych artykulacjach ${ }^{4}$. Hiszpańskie horrory, jak Sierociniec (El orfanato, reż. Juan Antonio Bayona, 2007) czy Oczy Julii (Los ojos de Julia, reż. Guillem Morales, 2010), oglądane poza granicami kraju mogą uchodzić za absolutnie transnarodowe (w tym wypadku: wyzbyte cech kina narodowego) ${ }^{5}$, natomiast komedie z powo-

${ }^{2}$ Strukturę i trendy hiszpańskiego box office'u (w latach 2001-2015) analizowałam w artykule Przeboje najnowszego kina hiszpańskiego (2001-2015), [w:] Przeboje z różnych stron, red. A. Lewicki, J. Grębowiec, Kraków 2017, s. 81-98.

${ }^{3}$ S. Marsh, Comedy in Spanish Cinema: An Overview, [w:] A Companion to Spanish Cinema, red. J. Labanyi, T. Pavlović, Hoboken 2013, s. 194.

${ }^{4}$ B. Jordan, R. Morgan-Tamosunas, Contemporary Spanish Cinema, Manchester 1998, s. 62.

${ }^{5}$ Pojęcia transnarodowości używam tutaj za Mette Hjort, która nalega na traktowanie tego pojęcia w formie skali, na której można umieszczać dany utwór filmowy (i traktować go jako silniej lub słabiej transnarodowy) po przeanalizowaniu go według parametrów produkcji, dystrybucji, recepcji i/lub treści. W tym wypadku o transnarodowości hiszpańskich horrorów może świadczyć przede wszystkim analiza treści. Zob. M. Hjort, On The Plurality of Cinematic Transnationalism, [w:] World Cinemas, Transnational Perspectives, red. N. Durovicova, K. Newman, Routledge-New York-London 2010, s. 12-33. Nic dziwnego zatem, że poza granicami Hiszpanii to hiszpańskie filmy grozy oglądane są znacznie chętniej, zgodnie z tezą Arkadiusza Lewickiego, który pisał: „Najlepiej sprzedają się bowiem utwory, których narodowa przynależność jest ukrywana i które są (lub przynajmniej udają) produkcje ponadnarodowe, a może po prostu amerykańskie" (A. Lewicki, Analiza box office’ów jako narzędzie badań filmoznawczych, „Kwartalnik Filmowy” 2014, nr 85, s. 126). 
du silnego zakorzenienia w tradycji i narodowej specyfice zdają się sytuować po przeciwnej stronie skali.

Marsh stwierdza, że naturę komedii można odnaleźć w jej trzech podstawowych typach, które definiuje jako: (1) konserwatywny (conservative), (2) subwersywny i transgresyjny (subversive and transgresive) oraz (3) reakcyjny (reactionary $)^{6}$. Humor w komedii pierwszego typu polega na wprowadzaniu widza w dobre samopoczucie, aby uodpornić go na wpływy trudnej rzeczywistości. Typ drugi umożliwia stworzenie „krytycznego lustra dla korupcyjnej, zadowolonej z siebie i obłudnej władzy" ". Trzeci rodzaj to komedie pełne rasistowskich, seksistowskich czy homofobicznych żartów. Autor zaznacza jednak, że nie ma konsensusu co do natury klasycznej filmowej komedii hiszpańskiej: czy tą narodową formą będzie komedia konserwatywna, czy subwersywna - wielokrotnie bowiem hiszpańską komedię uznawano za (nazbyt) konwencjonalną, a część popularnych reżyserów komedii (Luis García Berlanga czy Marco Ferreri) krytykowano właśnie za konserwatyzm ${ }^{8}$. Według Marsha mimo trudności w określeniu sedna komedii panuje jednak powszechna zgoda co do tego, że komedia pozostaje w relacji z kulturowymi tożsamościami będącymi łącznikiem między komedią a narodowym bądź etnicznym dyskursem ${ }^{9}$. Co więcej, rzekomo konserwatywna natura gatunku związana jest z jego zwyczajowym dążeniem do rozwiązania konfliktu ${ }^{10}$.

\section{Komedia we współczesnym kinie hiszpańskim}

Początek współczesnego kina hiszpańskiego wyznaczyły przemiany społeczno-polityczne, które miały miejsce w kraju w momencie zakończenia reżimu i transformacji ustrojowej po śmierci Francisca Franco w 1975 roku (pierwsze wolne wybory odbyły się w 1977 roku, a do najważniejszych zmian należą chociażby zniesienie cenzury w 1977 czy depenalizacja homoseksualizmu w 1979 roku). Początek lat 80. przyniósł kinematografii przede wszystkim istotne zmiany legislacyjne. W 1982 roku naczelną dyrektorką Kinematografii (Directora General de Cinematografía) została reżyserka filmowa Pilar Miró. Na początku 1984 roku pod jej przewodnictwem wprowadzono tak zwane Prawo Miró (Ley Miró), które do dzisiaj wzbudza wiele kontrowersji ${ }^{11}$. Autorki książki 100 Years

${ }^{6}$ S. Marsh, op. cit., s. 194.

${ }^{7}$ Ibidem.

${ }^{8}$ S. Marsh, Popular Spanish Film under Franco. Comedy and the Weakening of the State, Basingstoke 2006, s. 2.

${ }^{9}$ S. Marsh, Comedy in Spanish Cinema ..., s. 194.

10 S. Marsh, Popular Spanish Film ..., s. 2.

11 Barry Jordan stwierdza, że Prawo Miró miało „niszczycielski” wpływ na produkcję filmową w Hiszpanii, a nowa legislacja stanowiła formę politycznej manipulacji. Peter Besas natomiast zwraca uwagę na fakt, iż kryteria przyznawania dotacji były niejasne i na tyle mętne, by mógł zostać 
of Spanish Cinema zwracają uwagę na to, że nowe prawo odzwierciedlało politykę będącego wówczas u władzy socjalistycznego rządu poprzez interwencję w produkcję kulturalną za pomocą publicznych subsydiów ${ }^{12}$. Zespół pod kierownictwem Miró, przyznający dofinansowania, faworyzował przede wszystkim tak zwane kino jakości ${ }^{13}$ - w praktyce były to głównie adaptacje „,wielkiej” literatury (z myślą o ugruntowaniu pozycji kina hiszpańskiego na międzynarodowym rynku festiwalowym) oraz artystyczne eksperymenty dla widzów o bardzo wyszukanych gustach. Zapomniano jednak o potrzebach masowej widowni, wykluczając z puli dofinansowań produkcje niskobudżetowe oraz kino gatunkowe, przede wszystkim horrory i miękką pornografię, które do tej pory cieszyły się ogromnym powodzeniem ${ }^{14}$. Mimo takiej polityki ze strony rządu komedia była gatunkiem, który rozwijał się bardzo dobrze. Według Jordana i Morgan-Tamosunas dominacja, popularność i komercyjny sukces komedii w postfrankistowskiej Hiszpanii jest wynikiem jej długiej tradycji w hiszpańskim kinie:

Podczas ery Franco, obok walk byków i piłki nożnej, lekkie komedie oferowały wygodne urozmaicenie od nieco bardziej kontrowersyjnych tematów, jak polityka. Co więcej, zapewniały także efektywny mechanizm przekazywania konserwatywnych wartości reżimu ${ }^{15}$.

Jordan i Morgan-Tamosunas wymieniają trzy podstawowe podgatunki, które można wyodrębnić w hiszpańskiej kinematografii czasów transformacji (i które jednocześnie są kulturowym spadkiem poprzednich dekad):

1. comedia sexy nastawiona na estetykę groteski i sporą dawkę dosyć śmiałej erotyki. Jednocześnie, na co wskazują Pablo Pérez Rubio i Javier Hernández Ruíz, ten podgatunek komedii był próbą nieśmiałej krytyki frankistowskiego porządku moralnego, nie mógł też pozostać obojętny wobec nowej klasy rządzącej ${ }^{16}$. Nie gloryfikował również tradycyjnego wizerunku mężczyzny, zakorzenionego w machismo (czyli postawie przesadnej manifestacji silnego poczucia męskości i dumy), przeciwnie — podchodził do niego z dużą dozą ironii i krytyki;

wcielony polityczny oraz personalny faworytyzm. Zob. B. Jordan, The Spanish Film Industry In The 1980s and 1990s, [w:] Contemporary Spanish Cultural Studies, red. B. Jordan, R. Morgan-Tamosunas, London-New York 2000, s. 182-183; P. Besas, The Financial Structure of Spanish Cinema, [w:] Refiguring Spain. Cinema, Media, Representation, red. M. Kinder, Durham-London 1997, s. 246.

12 T. Pavlović et al., 100 Years of Spanish Cinema, Oxford 2007, s. 154.

13 „Kino jakości” to raczej etykieta niż termin. Jej geneza sięga pierwszej połowy XX wieku i opisuje przede wszystkim filmy europejskie, które tworzono zgodnie z powszechnym przekonaniem klasy średniej na temat sztuki. Philip Simpson opisuje to przekonanie jako ukształtowane przez klasyczną literaturę oraz ideologię humanistyczną i zaznacza, że filmy tworzone według tego klucza jakości nie cieszyły się szczególną popularnością poza granicami państwa, z którego pochodziły. Zob. Critical Dictionary of Film and Television Theory, red. R.E. Pearson, P. Simpson, London-New York, s. 30.

14 Zob. T. Pavlović et al., op. cit., s. 154.

15 B. Jordan, R. Morgan-Tamosunas, op. cit., s. 63-64.

16 P. Pérez Rubio, J. Hernández Ruíz, Esperanzas, compromisos y desencantos. El cine durante la transición española, [w:] La nueva memoria. Historia(s) del cine español (1939-2000), red. L. Castro de Paz, J. Pérez Perucha, S. Zunzunegui, A Coruña 2005, s. 190. 
2. „komedia prawicowa”, jak określają ją Jordan i Morgan-Tamosunas (right-wing comedy), miała tendencję do satyryzowania czy wręcz demonizowania ówczesnej sytuacji politycznej (czyli okresu transformacji i ugruntowania demokracji) ${ }^{17}$;

3. parodie historyczne były, według Jordana i Morgan-Tamosunas, produktem zmieszania cech filmów z grupy pierwszej i drugiej ${ }^{18}$.

Pomimo pozornie dobrej koniunktury już na początku lat 80 . te charakterystyczne podgatunki przeżyły poważny kryzys: jak wspomniano, organy odpowiedzialne za subsydiowanie kinematografii pod przewodnictwem Pilar Miró nie przewidywały dofinansowań dla tego rodzaju kina. Ponadto w tym samym czasie w Hiszpanii pojawiły się tak zwane „sale X” — kina, w których wyświetlano filmy pornograficzne. $Z$ tego powodu iberyjska komedia erotyczna przestała być atrakcyjna dla wielu widzów, którzy do tej pory poszukiwali w niej przede wszystkim uciech natury zmysłowej ${ }^{19}$. Jednak niezależnie od tych trzech bardzo popularnych trendów w hiszpańskiej komedii czasów transformacji w końcu lat 70. pojawił się nurt, który nazwano Nową Komedią Madrycką (Nueva Comedia Madrileña) — ze względu na miejsce, w którym się rozwinął — i to w jego ramach powstało najwięcej ważnych filmów. W porównaniu z innymi wytworami o charakterze komediowym był to nurt innowacyjny, jednak według Marsha wykazywał niechęć do całkowitego zerwania z przeszłością czy tradycją (mimo tego, co potocznie uważa się o wielu filmach z okresu wczesnej demokracji) ${ }^{20}$. Nowa Komedia Madrycka nie wywodziła się jednak z wymienionych najpopularniejszych podgatunków komedii epoki przemian ustrojowych. Jej źródeł należy upatrywać w nurcie tercera vía, który powstał nieco na uboczu, a jego głównymi twórcami byli scenarzysta i producent José Luis Dibildos oraz reżyserzy Antonio Drove i Roberto Bodegas ${ }^{21}$. Filmy należące do nurtu tercera vía charakteryzowały się ,dyskursem afirmującym stereotyp nowej burżuazji liberalnej w środku procesu modernizacji i adaptacji do nowych czasów" 22 i to one zainspirowały twórczość komediową między innymi Fernanda Trueby (nagrodzonego Oscarem w 1994 roku za Belle Epoque w kategorii najlepszy film nieanglojęzyczny), Emilia Martíneza Lázaro oraz Fernanda Colomo, którego film Tigres de Papel (1977) uznawany jest za początek Nowej Komedii Madryckiej. Reżyserzy tego nurtu bohaterami swoich filmów uczynili przede wszystkich młode generacje lat 70., czyli ówczesnych dwudziesto- i trzydziestolatków. Początkowo akcja obrazów umieszczona była przede wszystkim w tętniącym życiem, miejskim otoczeniu. Jordan i Morgan-Tamosunas, charakteryzując Nową Komedię Madrycką, piszą, że filmy

${ }_{17}^{17}$ B. Jordan, R. Morgan-Tamosunas, op. cit., s. 65.

18 Ibidem, s. 64-66.

${ }^{19}$ Ibidem, s. 66.

20 S. Marsh, Comedy in Spanish Cinema ..., s. 196.

${ }^{21}$ Do najważniejszych filmów tego nurtu należą Españoles en París (reż. Roberto Bodegas, 1970) oraz Tocata y fuga de Lolita (reż. Antonio Drove, 1974).

22 P. Pérez Rubio, J. Hernández Ruíz, op. cit., s. 217. 
te skupiały się na emocjonalnych problemach (małżeństwo, rozwód, separacja, wychowywanie dzieci, ograniczenia na tle seksualnym itp.) swoich młodych bohaterów, opierały głównie na często improwizowanych dialogach i wydawały się „żądać zwrotu emocjonalnej przeszłości, odmówionej im przez frankistowską represję"23.

Przełom lat 70. i 80. XX wieku to również czas rozwoju kariery Pedra Almodóvara, prawdopodobnie najpopularniejszego poza granicami kraju hiszpańskiego reżysera, który przez wielu akademików uznawany jest za zupełnie osobny „fenomen" 24 . Jego pierwsze filmy mogą być uznane za komedie, które skupiały się przede wszystkim na odwróceniu tradycyjnych opozycji płciowych oraz krytycznym podejściu do tradycyjnego patriarchatu i wartości utrwalonych przez reżim w formie skostniałych, stereotypowych konstruktów (jak rodzina i religia). Podstawowymi kategoriami estetycznymi wykorzystywanymi przez Almodóvara były skłonność do przesady i parodia ${ }^{25}$, a także estetyka kampowa (źródła humoru $\mathrm{w}$ kinie tego reżysera odnajdziemy bowiem nie tylko w dialogach i zdarzeniach, lecz także postaciach oraz konstrukcji świata przedstawionego). Jednocześnie, na co zwracają uwagę Josetxo Cerdán i Javier Pena, tym, co w wypadku Almodóvara zaskakuje najbardziej (i jest jednocześnie najbardziej znaczącą cechą jego filmowej twórczości) to fakt, że wewnątrz kina hiszpańskiego stanowi on przypadek bez precedensu, autonomiczny i indywidualny, który, chociaż wpłynął na wielu późniejszych reżyserów, nie był punktem zapalnym do pojawienia się tak zwanej szkoły:

z tego punktu widzenia bardziej, niż o szkole, możemy mówić o Almodóvarze, który otwarł nowe drogi, poddawszy recyklingowi elementy hiszpańskiej tradycji, od odzyskania sainete w traktowaniu motywów religijnych lub stylów muzycznych jak copla i bolero, zawsze z właściwą sobie rzutkością 26 .

W wypadku Almodóvara możemy zatem mówić o komedii autorskiej — reżyser często bywa autotematyczny, odnajdując źródło komizmu w powtarzaniu własnych żartów bądź typów osobowościowych znanych z jego poprzednich filmów ${ }^{27}$.

Transformacje społeczno-polityczne w Hiszpanii oraz idące za nimi zmiany legislacyjne miały niebagatelny wpływ na ewolucję komedii w najnowszym ki-

${ }^{23}$ B. Jordan, R. Morgan-Tamosunas, op. cit., s. 69.

${ }^{24} \mathrm{~W}$ ten sposób Almodóvar prezentowany jest między innymi w książkach T. Pavlović et al., op. cit. czy La nueva memoria. Historia(s) del cine español (1939-2000).

${ }^{25}$ B. Jordan, R. Morgan-Tamosunas, op. cit., s. 143.

26 J. Cerdán, J. Pena, Variaciones sobre la incertidumbre (1984-2000), [w:] La nueva memoria, s. 290. Sainete to rodzaj jednoaktowej, operowej farsy, popularnej w Hiszpanii między XVII a XX wiekiem. Copla to forma popularnej piosenki, wywodząca się z Andaluzji (która pomimo swojej długiej tradycji szczególną sławę zdobyła w latach 30. i 40. XX wieku). Bolero jest natomiast rodzajem tańca, a jego pochodzenie datuje się na XIX wiek (istnieje również kubańska odmiana bolero, oba warianty mają jednak różną genezę).

27 Znakomitym przykładem filmu wykorzystującego tę strategię są Przelotni kochankowie (Los amantes pasajeros, 2013). 
nie hiszpańskim. Przyglądając się hiszpańskim komediom filmowym od lat 90., ponownie można wyodrębnić jej podgatunki. Komedie obyczajowe i komediodramaty takich reżyserów, jak Daniel Sánchez Arévalo czy David Trueba będą miały najwięcej wspólnego z Nową Komedią Madrycką — tak samo jak filmy Emilia Martíneza Lázaro związanego, jak już zostało wspomniane, z tym nurtem od lat 80. Czarne komedie i pastisze w wykonaniu Santiaga Segury bądź Álexa de la Iglesii wiele zawdzięczają twórczości Pedra Almodóvara. Komedie science fiction i komedie romantyczne (które tworzą między innymi Nacho Vigalondo, María Ripoll czy Javier Ruiz Caldera) są najprawdopodobniej wyrazem inspiracji odnajdowanych w kinie amerykańskim ${ }^{28}$. Jednak wyjątkową cechą współczesnych komedii hiszpańskich jest ich skłonność do seryjności, otwartość na sequele i umiejętność zainteresowania publiczności bardzo podobnymi historiami przez kilka (jeśli nie kilkanaście) lat. Najbardziej emblematyczne przykłady znajdziemy w filmografiach Emilia Martíneza Lázaro oraz Santiaga Segury.

Arkadiusz Lewicki, powołując się na badania Jeremy’ego G. Butlera, analizuje amerykański system telewizyjny i zauważa, że jest on niestabilny z powodu zmian, jakie nastąpiły w ostatnich kilku dekadach, a które można podsumować jako nacisk konwergencji telewizji ogólnodostępnych i kablowych, filmów kinowych oraz technologii komputerowych. Lewicki zaznacza, że podobne zjawiska można obserwować również na innych rynkach (także hiszpańskim) i pisze, że

Wszystkie te procesy sprawiają, że dystans między telewizją a kinem zmniejszył się dziś w sposób niezwykle znaczący i mamy do czynienia z coraz bardziej filmową telewizją i coraz mocniej telewizyjnym filmem, a jednym z najciekawszych przykładów medialnej konwergencji są współczesne seriale telewizyjne i kinowe przeboje z ostatnich lat ${ }^{29}$.

Jedną z konsekwencji tych procesów jest zwiększenie zainteresowania seriami filmowymi (które oczywiście nie są w kinie niczym nowym). Kino głównego nurtu, według Lewickiego, upodabnia się do telewizji (w której naturę wpisana jest seryjność) — w swojej książce autor analizuje rynek amerykański, lecz szybki rekonesans w rzeczywistości hiszpańskiej naprowadzi nas na podobną prawidłowość: wśród trzydziestu najpopularniejszych filmów hiszpańskich siedem to filmy przynależne do serii bądź zależności oryginał-sequel, w tym trzy znajdują się w pierwszej dziesiątce ${ }^{30}$. Co więc decyduje o powstaniu hiszpańskiej serii lub kontynuacji komediowej?

${ }^{28}$ Z kina amerykańskiego wywodzi się również konwencja buddy movie (filmu kumpelskiego), którą w wersji komediowej odnajdziemy w kinie hiszpańskim, na przykład w filmie Kuzyni (Primos, 2011) Daniela Sáncheza Arévalo lub Truman (2015) Cesca Gaya (w tym wypadku mamy jednak do czynienia z komediodramatem).

29 A. Lewicki, Od House'a do Shreka. Seryjność w kulturze popularnej, Wrocław 2011, s. 30-31.

${ }^{30} \mathrm{~W}$ zestawieniach najbardziej kasowych filmów w Hiszpanii można zaobserwować również powtarzalność reżyserów: w pierwszej dziesiątce Emilio Martínez-Lázaro pojawia się dwa razy, natomiast Juan Antonio Bayona i Alejandro Amenábar — po trzy razy. Nieco inaczej wyglądają zestawienia najchętniej oglądanych filmów hiszpańskich na świecie: Bayona i Amenábar utrzymują 


\section{Serie komediowe. Santiago Segura i Emilio Martínez Lázaro}

Początek lat 90. w kinie hiszpańskim upłynął pod znakiem głębokiego kryzysu (w 1994 roku wyprodukowano jedynie 44 filmy, czyli najmniej w całej dekadzie 1991-2000). Bez wątpienia największy wpływ miała na to destabilizacja przemysłu kinematograficznego związana z rozwojem kanałów telewizyjnych i zwiększeniem oferty audiowizualnej w telewizji, lecz także gwałtownym wzrostem popularności technologii video i coraz bardziej stanowczym rozróżnianiem przez widzów filmów na cine de butaca (filmy do oglądania w kinowym fotelu, przede wszystkim superprodukcje) i cine de casa (kino do oglądania w domu). Jednak już w połowie dekady można było mówić o odwróceniu się fortuny ${ }^{31}$ (w 1995 roku wyprodukowano 59 filmów, w 1996 roku - 91). Paradoksalnie w latach 90. można było zaobserwować szczególnie ważny fenomen: jakby nie zważając na kryzys, pojawiło się w Hiszpanii wielu nowych reżyserów (autorów swoich pierwszych i drugich filmów pełnometrażowych), którzy są aktywni w kinie hiszpańskim do dziś (Isabel Coixet, Icíar Bollain, Agustín Díaz Yanes, Julio Medem, Alejandro Amenábar czy Fernando León de Aranoa) ${ }^{32}$.

I właśnie do tej grupy ważnych debiutantów należy zaliczyć również Santiaga Segurę, autora serii Torrente (do tej pory w latach 1998-2014 w ramach tej serii powstało pięć filmów) opowiadającej o perypetiach policjanta José Luisa Torrente. Segura, reżyser filmu i jednocześnie odtwórca głównej roli, nazywany jest przez autorki książki 100 Years of Spanish Cinema jednym z „bękarcich synów postmoderny lat osiemdziesiątych" (razem z Alejandrem Amenábarem, Juanmą Bajo Ulloą, Mateo Gilem i Álexem de la Iglesią) — reżyserów tworzących w świecie globalnej ekonomii i nowoczesnych technologii komunikacji, gdzie kultura łączy się z wypoczynkiem, sprzedażą doświadczeń i stylów życia33. Jordan i Morgan-Tamosunas stwierdzają, że postmodernistyczne komedie (takie jak filmy o Torrente) wymykają się ścisłym definicjom, właśnie poprzez ich „ostentacyjnie hybrydyczny, międzygatunkowy charakter oraz pogardę dla ustalonych filmowych reguł, jak również innych kulturowych i społecznych barier czy hierarchii" 34. Również źródła komizmu w tych komediach wydają się dosyć

swoją pozycję, jednak Martínez-Lázaro ustępuje miejsca Pedro Almodóvarowi, którego filmy są nieco chętniej oglądane poza granicami Hiszpanii niż w kraju.

31 Por. C.F. Heredero, A. Santamarina, Semillas de futuro. Cine español 1990-2000, Madrid 2002; E. Rodríguez Merchán, G. Fernández-Hoya, La definitiva renovación generacional (19902005), [w:] Miradas sobre pasado y presente en el cine español (1990-2005), red. P. Feenstra, Hub. Hermans, „Foro Hispánico” 32, Colección Hispánica de Flandes y Países Bajos, Amsterdam-New York 2008, s. 23-38.

32 Szczegółowo o fenomenie piszą między innymi Carlos F. Heredero i Antonio Santamarina, op. cit., s. 49.

33 T. Pavlović et al., op. cit., s. 184.

34 B. Jordan, R. Morgan-Tamosunas, op. cit., s. 81. 
nietypowe. Polega on przede wszystkim na umyślnym zakłóceniu oczekiwań widzów oraz zestawieniu dziwności, banału i groteski z hedonistyczną pogonią za przyjemnością, co pozostaje $\mathrm{w}$ zgodzie $\mathrm{z}$ cudacznymi bohaterami ${ }^{35}$. Za takiego właśnie protagonistę może zostać uznany również tytułowy bohater serii Torrente: policjant mieszka w Madrycie, jest leniwy, nieszczególnie inteligentny, nie stroni od alkoholu i chętnie prezentuje swoje seksistowskie, rasistowskie i ekstremalnie prawicowe poglądy. Autorki 100 Years... premierę pierwszej części sagi o komisarzu Torrente, czyli filmu Torrente: Przygtupia ręka sprawiedliwości (Torrente, el brazo tonto de la ley, reż. Santiago Segura, 1998), określają mianem „mass medialnego wydarzenia w przemyśle rozrywkowym” Hiszpanii ${ }^{36}$, a źródeł powodzenia filmu o tak specyficznym bohaterze należy poszukiwać w konstrukcji świata przedstawionego, dobrej znajomości potrzeb publiczności, nagminnym korzystaniu z klisz popkulturowych oraz strategii marketingowej. Główni bohaterowie obrazu, Torrente i jego sąsiad Rafi, przywodzą na myśl filmy o antybohaterskich policjantach-głupkach (ważnym odniesieniem będzie tu porucznik Frank Drebin, bohater grany przez Leslie Nielsena w serii Naga brońn ${ }^{37}$ oraz komedie slapstickowe. Nietrudno też odnaleźć odniesienia do mainstreamowego kina Hollywood: Lidia Merás zwraca uwagę przede wszystkim na film Kobra (Cobra, reż. George P. Cosmatos, 1986), którego tytuł w Hiszpanii thumaczony był jako Cobra, el brazo fuerte de la ley (Kobra, mocne ramię prawa bądź, zachowując analogię do thumaczenia polskiego filmu o Torrente, Kobra, mocne ramię sprawiedliwości). W filmie Cosmatosa w roli tytułowej wystąpił Sylvester Stallone, który obok Stevena Seagala pojawił się również w trailerze Torrente jako analogia — obaj aktorzy mają w swoich filmografiach role policjantów nadużywających swoich uprawnień ${ }^{38}$. Merás zauważa, że ta strategia została powtórzona w kolejnych częściach sagi i wśród intertekstów oraz inspiracji wymienia również powieść pikarejską, innych przedstawicieli kina amerykańskiego (Martina Scorsesego czy Groucho Marxa), lecz także kina hiszpańskiego (Luisa Garcii Berlanga czy Josego Luisa Lopeza Vazqueza), telewizję (Benny Hill, seksistowskie reklamy z lat 60.), a także dwa popularne style filmowe z późnego okresu frankizmu — landismo i destape ${ }^{39}$. Ponadto na powodzenie serii wpłynęły również decyzje obsadowe: nieoczywisty casting (tutaj na szczególną uwagę zasługuje obsadze-

${ }^{35}$ Ibidem.

36 T. Pavlović et al., op. cit., s. 184.

37 A. Rico-Albero, Flexing Generic Boundaries: Torrente, [REC] and Adolescent Cinema in Spain, [w:] (Re)viewing Creative, Critical and Commercial Practices in Contemporary Spanish Cinema, red. D. Wheeler, F. Canet, Bristol-Chicago 2014, s. 327.

${ }^{38}$ L. Merás, The "Torrente" Tetralogy: A Homegrown Saga, [w:] (Re)viewing Creative..., s. 338.

39 Ibidem, s. 339. Landismo — w tym stylu filmowym lekka komedia łączyła się z erotyką (jednak mężczyźni często jawili się tu jako seksualnie uciśnieni). Destape to kino erotyczne, które pojawiło się w Hiszpanii po zniesieniu cenzury w 1977 roku. „Destape” oznacza „nagość”, lecz odnosi się także do liberalizacji idei i praktyk. Zob. L. Merás, op. cit., s. 347. 
nie Tony'ego Leblanca w roli ojca; aktor znany ze swoich ról w hiszpańskich komediach z lat 60 . i 70. za sprawą serii został przedstawiony lub przypomniany nowej generacji widzów ${ }^{40}$ ) i liczne cameo, czyli epizodyczne udziały znanych osobistości w filmach serii. Lidia Merás dokonuje pewnej typologii cameo pojawiających się w sadze Torrente i dzieli je na „cameo prestiżowe” (Oliver Stone pojawił się w trzeciej części sagi, często są to znani przedstawiciele hiszpańskiego systemu gwiazdorskiego, jak Gabino Diego, Jorge Sanz, Jose Luis López Vazquez czy piłkarze Realu Madryt) oraz „,cameo celebryckie” (przez kilka chwil na ekranie pojawiają się również osoby, które w Hiszpanii sławne są głównie z tego, że pochodzą ze znanej rodziny, jak Carmen Martínez-Bordiú, wnuczka caudillo Francisca Franco, bądź z tego, że „są znane”, jak celebrytka Belen Esteban) ${ }^{41}$. Większość z tych strategii jest jednak nieidentyfikowalna poza Hiszpanią, nie dziwią zatem dosyć rozczarowujące wyniki sagi Torrente za granicą (nie wszystkie części doczekały się w ogóle zagranicznej dystrybucji) ${ }^{42}$.

Recepcja to bardzo ważne uzupełnienie dyskursu o serii Torrente. Jay Beck i Vicente Rodríguez Ortega podkreślają, że twórcy filmów zauważyli istotną niszę w hiszpańskim rynku filmowym: grupą docelową od początku byli tu bowiem młodzi ludzie (głównie mężczyźni), którzy nie za bardzo znajdowali coś dla siebie w kinie Hiszpanii ${ }^{43}$. W końcu w osiągnięciu ogromnej popularności pomogła serii Santiaga Segury intensywna kampania marketingowa. Poza zwyczajowymi plakatami promocji serii towarzyszyła kampania telewizyjna w bardzo nieformalnym rejestrze: Segura używał slangu, zwracając się do swojej potencjalnej publiczności (mówił o nich amiguetes, kumple, zapraszając do wspólnej kinowej przygody), co tylko potwierdza jego dużą świadomość potrzeb i zainteresowań widzów $^{44}$. Rico-Albero zwraca również uwagę na to, że spolaryzowana recepcja (film był z jednej strony krytykowany za banalność, skatologiczny humor i kreowanie bohatera tak silnie związanego z negatywnymi stereotypami zakorzenionymi we frankizmie, ale chwalony za postmodernistyczną grę i swoistą perwersję w artykułowaniu tych stereotypów w celu ich krytyki) miała równie pozytywny wpływ na wyniki box office' $u^{45}$. Merás zauważa, że o fenomenie świadczy dodatkowo, że Torrente obronił się w momencie, kiedy w Hiszpanii zaczęto szczególnie zaciekle walczyć z piractwem, zdefiniowawszy uprzednio ten problem rynku

${ }^{40}$ A. Rico-Albero, op. cit., s. 325.

${ }^{41}$ L. Merás, op. cit., s. 340.

42 Według danych z bazy Lumiere przygotowywanej przez European Audiovisual Observatory pierwsza część sagi poza granicami Hiszpanii pomogła zgromadzić w kinach około 28 tys. widzów (we Francji i Grecji), druga i trzecia w ogóle nie doczekały się dystrybucji poza Hiszpanią, czwarta - około 3 tys. (we Włoszech i w Niemczech), a piąta - 14 tys. na Węgrzech. Zob. http:// lumiere.obs.coe.int/web/search/index.php (dostęp: 20.08.2016).

43 J. Beck, V. Rodríguez Ortega, Introduction, [w:] Contemporary Spanish Cinema and Genre, red. J. Beck, V. Rodríguez Ortega, Manchester 2008, s. 14.

${ }^{44}$ A. Rico-Albero, op. cit., s. 327.

${ }^{45}$ Ibidem, s. 329. 
filmowego (2011 rok), kiedy coraz więcej osób coraz chętniej sięga po filmy na urządzeniach mobilnych, omijając kina (które z kolei przenoszą się do multipleksów na obrzeża miast). I podczas gdy przeciętny film hiszpański wchodzi do kin w średniej liczbie stu kopii, Torrente 3 pojawił się w 465 kopiach, a Torrente 4 — w $666^{46}$. Według Merás największym osiągnięciem Santiaga Segury jest bez wątpienia to, że potrafił przyciągnąć tych, którzy do tej pory w ogóle nie chodzili do kina, przy wykorzystaniu nietypowej recepty: zbudowaniu autorskiej wariacji hiszpańskiego modelu kina popularnego ${ }^{47}$.

Kolejnym ważnym fenomenem we współczesnej panoramie komedii hiszpańskich są filmy Emilia Martíneza Lázaro: Po drugiej stronie tóżka (El otro lado de la cama, 2002) i jego sequel Dwie strony tóżka (Los 2 lados de la cama, 2005) oraz Hiszpański temperament (Ocho apellidos vascos, 2014) i jego sequel Jak zostać Katalonka (Ocho apellidos catalanes, 2015) ${ }^{48}$.

Film Po drugiej stronie tóżka opowiada o perypetiach grupy znajomych trzydziestolatków: głównymi bohaterami są Pedro i Paula oraz Javier i Sonia tworzący dwie pary i jednocześnie uwikłani w romanse między sobą. Jak pisze Marina Díaz López, film zawdzięcza swój sukces przemyślanej kombinacji: reżysera (związanego z bardzo popularną niegdyś Nową Komedią Madrycką), obsady (wśród aktorów dominują osoby o proweniencji teatralnej) oraz wplecionych w fabułę numerów muzycznych (odwołujących się do złotej epoki hiszpańskiego popu) ${ }^{49}$. Film od strony formalnej rzeczywiście można określić jako komedię muzyczną, a musical bez wątpienia, tak samo jak komedia, silnie wpisuje się w tradycję filmowej Hiszpanii. Díaz López zauważa, że wstawki muzyczne pojawiają się zazwyczaj w finale scen, kiedy bohaterowie zostają sami, a piosenki, jak w tradycyjnym musicalu, służą zajrzeniu do świata wewnętrznego ${ }^{50}$ — innymi słowy, elementy musicalowe pomagają wyrazić to, czego nie jest w stanie zrobić dialog. Badaczka wskazuje również, że struktura filmu ma wiele wspólnego z klasyczną komedią teatralną, comedia de enredo, którą charakteryzowała skomplikowana fabuła i zaskakujący finał (w wypadku Po drugiej stronie łóżka męscy bohaterowie w tym samym czasie dowiadują się o zdradach swoich partnerek, postanawia-

46 L. Merás, op. cit., s. 345.

47 Ibidem, s. 346.

48 Polskie tytuły podaję za danymi z portalu Filmweb. Dosłowne tłumaczenie tytułu Ocho apellidos vascos to „Osiem baskijskich nazwisk” i jest to aluzja do jednego z istotniejszych motywów-gagów filmu (analogicznie: sequel nawiązuje do tytułu swojego poprzednika i Ocho apellidos catalanes przetłumaczymy jako „Osiem katalońskich nazwisk”). Pojawiające się gdzieniegdzie tytuły „Jak zostać Baskiem”/,Jak zostać Katalonką” to prawdopodobnie propozycje thumaczeń pochodzące z Tygodnia Kina Hiszpańskiego, który co roku organizowany jest przez firmę Mañana. Hiszpański temperament to $\mathrm{z}$ kolei tytuł, pod którym film pojawił się $\mathrm{w}$ dystrybucji $\mathrm{w}$ polskich kinach 2 grudnia 2016 roku (z ramienia firmy Best Film).

${ }^{49}$ M. Díaz López, ;Viva la diferencia (sexual)! o „El otro lado de la cama” (Emilio Martínez-Lázaro, 2002), [w:] Miradas sobre pasado y presente en el cine español (1990-2005)..., s. 151.

${ }^{50}$ Ibidem, s. 153. 
ją jednak pozostać w związkach i jednocześnie utrzymać nawiązane wcześniej romanse $)^{51}$. Można zatem wysnuć wniosek, że silne zakorzenienie filmu w tradycji zarówno teatralnej, jak i filmowej (ze względu na charakter filmu i osobę reżysera, lecz także inne inspiracje, które można datować nawet na lata 50. i komedie Luisa Garcíi Berlangi i Rafaela Azcony ${ }^{52}$ ) będzie dodatkowym źródłem jej powodzenia. Ponadto film powstał w 2002 roku — nowa generacja reżyserów lat 90. w swojej produkcji filmowej przełomu wieków często sięgała po tematy społecznie zaangażowane (jak przemoc domowa, bezrobocie, bieda czy prostytucja). Frywolna komedia jawiła się zatem jako mocny kontrapunkt w kinie - wytwór kultury utożsamiany przez wielu widzów z rozrywką i przyjemnością. Na podobną rzecz zwraca uwagę Díaz López i stwierdza, że film dobrze odpowiadał na potrzeby público veraniego, czyli publiczności letniej (publiczności „sezonu ogórkowego", która według autora chętniej ogląda niewymagające komedie niż kino artystyczne) - jego premiera miała bowiem miejsce 5 lipca ${ }^{53}$.

Do Martíneza Lázaro należy jeszcze jeden spektakularny sukces ostatnich lat. Peter Buse i Nuria Triana-Toribio w swoim artykule stwierdzają, że według wielu miar w filmie Hiszpański temperament nie odnajdziemy niczego szczególnego:

To najbardziej konwencjonalna z romantycznych komedii - piszą autorzy. - Opowiastka pełna przebieranek i niezrozumień o niedobranych i zwaśnionych kochankach, którzy po serii niefortunnych wypadków [...] kończą w swoich ramionach ${ }^{54}$.

Nie zmienia to faktu, że film o miłosnych perypetiach Baskijki i Andaluzyjczyka (który usiłuje potwierdzić swoje udawane baskijskie pochodzenie przed ojcem dziewczyny) jest jak do tej pory najchętniej oglądanym filmem w historii tej kinematografii. Buse i Triana-Toribio zaznaczają, że ten film (będący swoistym socjologicznym fenomenem) nie powstał jednak w próżni: po pierwsze, sytuuje się w aktualnym trendzie ,posthumoru” właściwym współczesnej kultury hiszpańskiej; po drugie, wykorzystuje konwencję komediową, by poruszyć istotne problemy różnic i konfliktów (oraz, bez wątpienia, różnic będących źródłem konfliktu) ${ }^{55}$; po trzecie, co warto dodać, eksploatuje temat stereotypów związanych z poszczególnymi regionami i czyni z niego jedno z głównych źródeł komizmu.

Film Martíneza Lázaro maksymalnie eksploatuje konwencję obśmiewania stereotypów związanych z regionalnymi różnicami, głęboko zakorzenionych w hiszpańskiej kulturze. Jednak najważniejszym konfliktem, który nie tylko zostaje wspomniany w filmie, lecz jest traktowany w sposób humorystyczny, nie jest, jakby

51 Ibidem, s. 155.

52 Ibidem, s. 158.

53 Ibidem, s. 161.

54 P. Buse, N. Triana Toribio, Ocho apellidos vascos and the Comedy of Minor Differences, „Romance Quarterly” 62, 2015, http://www.tandfonline.com/doi/full/10.1080/08831157.2015.1068 637 (dostęp: 20.01.2017).

55 Ibidem. 
się mogło wydawać, konflikt kulturowy między Krajem Basków a Andaluzją, lecz „problem baskijski”, czyli krwawy konflikt pomiędzy organizacją terrorystyczną ETA a państwem hiszpańskim, mający swoje początki w 1959 roku, który trwał jeszcze wiele lat po zakończeniu dyktatury. Formalny koniec konfliktu datuje się na 2011 rok, co oznacza, jak zauważają Buse i Triana-Toribio, że Hiszpański temperament wydaje się dosyć świeżym komentarzem do tych wydarzeń. Autorzy podkreślają, że omawiana komedia nie będzie raczej uznana za film, który dramatycznie zmieni sposób przedstawiania ETA w hiszpańskim kinie, motyw ten nie jest bowiem w żaden sposób wiodący u Martíneza Lázaro, a jawi się raczej jako „,fantazmat, produkt nieuzasadnionej andaluzyjskiej paranoi"56: gdy przyjaciel głównego bohatera dowiaduje się, że jego nowa przyjaciółka jest Baskijką, głośno zastanawia się nad jej potencjalnym powiązaniem z terroryzmem (w późniejszych scenach pojawiają się również aluzje do dążeń separatystycznych). Buse i Triana-Toribio podkreślają jeszcze jeden moment, w którym wspomniany zostaje terroryzm ETA: Koldo, ojciec głównej bohaterki, wdaje się w romans z Merche, którą uznaje za Baskijkę, po wspólnie spędzonej nocy Koldo odkrywa jednak, że w mieszkaniu kobiety pełno jest dowodów na jej kastylijskie pochodzenie oraz pamiątek po jej zmarłym mężu, członku guardia civil (hiszpańskiej straży obywatelskiej).

Film na tym jednak nie poprzestaje, skrywając jeszcze jedną podpowiedź: jaki mógł być główny powód dla członka guardia civil do przeprowadzki z Cáceres do Kraju Basków? Walka na froncie procesu pacyfikującego. A członkowie której z grup najczęściej ginęli z rąk ETA? Znów, guardia civil. To nie przeszkadza jednak Merche kochać jej adopcyjny kraj [...]. ETA pozostaje więc dalekim wspomnieniem na peryferiach filmu, budującą nieobecnością, a nie zagrażającą ${ }^{57}$.

I w tym kontekście szczególnie ważna jest wspomniana przez Busego i Trianę-Toribio konwencja ,posthumoru”, dla którego „nie ma świętości, nienazywalnych społecznych zjawisk, o których trzeba mówić z nabożnością, dreptania wokół świętych krów z całym arsenałem zaprzeczeń i sprostowań" ${ }^{28}$. To właśnie posthumor jest podejściem

cyrkulującym wokół tak zwanego problemu baskijskiego, tematu, który wzbudzał dyskomfort i niepokój w Hiszpanii przez dekady. Jednakże, ta strategia pomaga w zmniejszeniu potencjalnego dyskomfortu i ułatwia publiczności poradzenie sobie z trudnym tematem, który zostaje poruszony ${ }^{59}$.

W strategii posthumoru, zaznaczają autorzy, ważny okazuje się repertuar narzędzi, jakie są wykorzystywane przez twórców, w tym wypadku: casting związany choćby z pewną pozycją producenta w projekcie oraz uczuciami, jakimi obdarzani są aktorzy przez widzów (co może wpływać na odbiór filmu). Zainspirowani psychoanalitycznymi rozważaniami Freuda Buse i Triana-Toribio konkludują, że
56 Ibidem.
57 Ibidem.
58 Ibidem.
${ }^{59}$ Ibidem. 
posthumor może być ,post-" na dwa sposoby. Po pierwsze, wzbudza rozbawienie dokładnie dlatego, że bierze za temat bolesne tematy, lecz czyni je zabawnymi. Po drugie, traktuje te bolesne tematy w sposób humorystyczny, ale w tak dwuznaczny sposób, że śmiech wydaje się nieodpowiednią reakcją. W Hiszpańskim temperamencie mamy do czynienia z tą pierwszą strategią - trudno uznać ten film za subwersywny w ujmowaniu tematu terroryzmu. Przywołane wcześniej żarty są raczej banalne i stanowią zaledwie dodatek do fabuły, eksploatując bardziej temat stereotypów (czy raczej starszych i nowszych toposów) związanych z mieszkańcami Kraju Basków niż terroryzm sam w sobie.

Oba omówione filmy doczekały się swoich sequeli, które są ni mniej ni więcej jak przedłużeniem historii opowiedzianych w filmach je poprzedzających w Dwóch stronach tóżka przedstawiono dalsze losy (męskich) bohaterów dobrze znanych z części pierwszej. Z kolei w Jak zostać Katalonka perypetie miłosne bohaterów znanych z Hiszpańskiego temperamentu przenoszą się z Kraju Basków do Katalonii.

\section{Zakończenie}

Omówione sequele były nieco mniej popularne niż ich ekranowe pierwowzory. Jednak na podstawie ich analizy umieszczonej w kontekście historii najnowszej komedii hiszpańskiej można wysnuć pewne istotne wnioski dotyczące tego gatunku. Przede wszystkim publiczność w Hiszpanii bardzo chętnie powraca do znanych i lubianych bohaterów, co zdaje się wpisywać w globalny trend upodobania do seryjności w kulturze popularnej. Ponadto najchętniej oglądane komedie hiszpańskie nawiązują do wieloletniej tradycji tego kina — komedia nie tylko jest od wieków najpopularniejszym gatunkiem w hiszpańskiej kulturze, lecz współcześni twórcy filmowi w poszukiwaniu sukcesu łączą ją z innymi gatunkami kina popularnego (jak musical) bądź konwencjami. Inną ważną inspiracją jest tu też kino Hollywood. Wreszcie komedia pozwala na oswajanie tematów, które uznawane są za współczesne tabu (jak terroryzm) lub wciąż wzbudzają kontrowersje (mentalność społeczeństwa Hiszpanii z czasów Franco, machismo) oraz eksploatowanie konwencji, które są praktykowane w życiu codziennym (jak odnajdywanie źródła komizmu w stereotypowych wizerunkach mieszkańców poszczególnych regionów). 


\section{Bibliografia}

\section{Opracowania}

Besas P., The Financial Structure of Spanish Cinema, [w:] Refiguring Spain. Cinema, Media, Representation, red. M. Kinder, Duke University Press, Durham \& London 1997.

Contemporary Spanish Cinema and Genre, red. J. Beck, V.R. Ortega, Manchester University Press, Manchester 2008.

Critical Dictionary of Film and Television Theory, red. R.E. Pearson, P. Simpson, Routledge, London-New York 2001.

Díaz López M., ;Viva la diferencia (sexual)! o „El otro lado de la cama” (Emilio Martínez-Lázaro, 2002), [w:] Miradas sobre pasado y presente en el cine español (1990-2005), red. P. Feenstra, Hub. Hermans, „Foro Hispánico” 32, Colección Hispánica de Flandes y Países Bajos, Rodopi, Amsterdam-New York 2008.

Heredero C.F., Santamarina A., Semillas de futuro. Cine español 1990-2000, Sociedad Estatal España Nuevo Milenio, Madrid 2002.

Hjort M., On The Plurality of Cinematic Transnationalism, [w:] World Cinemas, Transnational Perspectives, red. N. Durovicova, K. Newman, Routledge, New York-London 2010.

Jordan B., The Spanish Film Industry In The 1980s and 1990s, [w:] Contemporary Spanish Cultural Studies, red. B. Jordan, R. Morgan-Tamosunas, Arnold Publishers, London-New York 2000.

Jordan B., Morgan-Tamosunas R., Contemporary Spanish Cinema, Manchester University Press, Manchester 1998.

Kaprzyk M., Przeboje najnowszego kina hiszpańskiego (2001-2015), [w:] Przeboje z różnych stron, red. J. Grębowiec, A. Lewicki, Wydawnictwo Libron, Kraków 2017.

Lewicki A., Analiza box office’ów jako narzędzie badań filmoznawczych, „Kwartalnik Filmowy” 2014, nr 85.

Lewicki A., Od House'a do Shreka. Seryjność w kulturze popularnej, Wydawnictwo Uniwersytetu Wrocławskiego, Wrocław 2011.

Marsh S., Comedy in Spanish Cinema: an Overview, [w:] A Companion to Spanish Cinema, red. J. Labanyi, T. Pavlović, Blackwell Publishing, Hoboken 2013.

Marsh S., Popular Spanish Film under Franco. Comedy and the Weakening of the State, Palgrave Macmillan, Basingstoke 2006.

Merás L., The „Torrente” Tetralogy: A Homegrown Saga, [w:] (Re)viewing Creative, Critical and Commercial Practices in Contemporary Spanish Cinema, red. D. Wheeler, F. Canet, Intellect, Bristol-Chicago 2014.

La nueva memoria. Historia(s) del cine español (1939-2000), red. J.L. Castro de Paz, J.P. Perucha, S. Zunzunegui, Vía Láctea Editorial, A Coruña 2005.

Pavlović T. et. al., 100 Years of Spanish Cinema, Wiley-Blackwell, Chichester-Oxford 2009.

Pérez Rubio P., Hernández Ruíz J., Esperanzas, compromisos y desencantos. El cine durante la transición española, [w:] La nueva memoria. Historia(s) del cine español (1939-2000), red. L. Castro de Paz, J. Pérez Perucha, S. Zunzunegui, La Coruña 2005.

Rico-Albero A., Flexing Generic Boundaries: Torrente, [REC] and Adolescent Cinema in Spain, [w:] (Re)viewing Creative, Critical and Commercial Practices in Contemporary Spanish Cinema, red. D. Wheeler, F. Canet, Intellect, Bristol-Chicago 2014.

Rodríguez Merchán E., Fernández-Hoya G., La definitiva renovación generacional (1990-2005), [w:] Miradas sobre pasado y presente en el cine español (1990-2005), red. P. Feenstra, Hub. Hermans, „Foro Hispánico” 32, Colección Hispánica de Flandes y Países Bajos, Rodopi, Amsterdam-New York 2008. 


\section{Źródla internetowe}

Buse P., Triana-Toribio N., Ocho apellidos vascos and the Comedy of Minor Differences, „Romance Quarterly" 62, 2015, http:/www.tandfonline.com/doi/full/10.1080/08831157.2015.1068637.

\section{This funny everyday life: Conventions and sources of humour in contemporary Spanish film comedies}

\section{Summary}

In the article, the author aims to organize and describe the most popular conventions of Spanish film comedy, as well as describe the sources of humor in these movies. Starting with the beginnings of contemporary (post-Franco) Spanish cinema, several important changes and developments are described. An economic and legal perspective provides background and a justification for the presented conventions. Additionally, several case-studies are analyzed, most importantly, films by Santiago Segura (the series of Torrente) and Emilio Martínez Lázaro (El otro lado de la cama, Los 2 lados de la cama, Ocho apellidos vascos and Ocho apellidos catalanes). 